\title{
Spatial patterns of aerobic and anaerobic mineralization rates and oxygen penetration dynamics in coral reef sediments
}

\author{
Ursula Werner ${ }^{1, *}$, Paul Bird ${ }^{2}$, Christian Wild ${ }^{1}$, Timothy Ferdelman ${ }^{1}$, Lubos Polerecky ${ }^{1}$, \\ Gabriele Eickert ${ }^{1}$, Ron Jonstone ${ }^{2}$, Ove Hoegh-Guldberg ${ }^{2}$, Dirk de Beer ${ }^{1}$ \\ ${ }^{1}$ Max Planck Institute for Marine Microbiology, Celsiusstr. 1, 28359 Bremen, Germany \\ ${ }^{2}$ Centre for Marine Studies, The University of Queensland, Brisbane, Queensland 4072, Australia
}

\begin{abstract}
Oxygen consumption rates (OCR), aerobic mineralization and sulfate reduction rates (SRR) were studied in the permeable carbonate reef sediments of Heron Reef, Australia. We selected 4 stations with different hydrodynamic regimes for this study. In situ oxygen penetration into the sediments was measured with an autonomous microsensor profiler. Areal OCR were quantified from the measured oxygen penetration depth and volumetric OCR. Oxygen penetration and dynamics (median penetration depths at the 4 stations ranged between 0.3 and $2.2 \mathrm{~cm}$ ), OCR (median 57 to $196 \mathrm{mmol} \mathrm{C} \mathrm{m} \mathrm{C} \mathrm{d}^{-1}$ ), aerobic mineralization (median 24 to $176 \mathrm{mmol} \mathrm{C} \mathrm{m}^{-2} \mathrm{~d}^{-1}$ ) and SRR (median 9 to

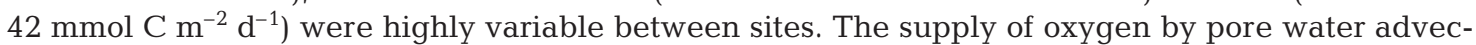
tion was a major cause for high mineralization rates by stimulating aerobic mineralization at all sites. However, estimated bottom water filtration rates could not explain the differences in volumetric OCR and SRR between the 4 stations. This suggests that local mineralization rates are additionally controlled by factors other than current driven pore water advection, e.g. by the distribution of the benthic fauna or by local differences in labile organic carbon supply from sources such as benthic photosynthesis. Carbon mineralization rates were among the highest reported for coral reef sediments, stressing the role of these sediments in the functioning of the reef ecosystem.
\end{abstract}

KEY WORDS: Coral reef · Permeable sands · Oxygen consumption · Sulfate reduction · Microsensors · In situ measurements

\section{INTRODUCTION}

In shallow coral reef systems, the carbonate sediments and reef framework are sites where a large fraction of the organic matter produced in the water column or by benthic primary production is mineralized (Clavier \& Garrigue 1999, Richter et al. 2001, Wild et al. 2004b). Consequently, sediments contribute strongly to an efficient element cycling within the reef system (Andrews \& Hans 1983, Rasheed et al. 2002, Wild et al. 2004a), which is the reason why coral reefs maintain their high biomass and high gross primary productivity, despite being situated in oligotrophic waters (Crossland \& Barnes 1983).
Unconsolidated carbonate sediments cover large areas within a coral reef (Capone et al. 1992, Clavier \& Garrigue 1999), however, little is known about aerobic and anaerobic mineralization processes within these sands. Sedimentary mineralization processes depend on transport mechanisms that provide electron donors and electron acceptors to the benthic system. Transport processes between water column and sediments include molecular diffusion, pore water advection, gravitational settling of particles, burial due to lateral sediment transport, and biological transport (bioturbation/bioirrigation) (Huettel \& Gust 1992, Shum \& Sundby 1996, Aller 2001). Coral reef sediments are highly permeable, reaching permeabilities of $10^{-9} \mathrm{~m}^{2}$ 
(Enos \& Sawatsky 1981, Wheatcraft \& Buddemeier 1981, Rasheed et al. 2003). In permeable sediments, the advective circulation of bottom water through the sediments (i.e. pore water advection) is considered a major transport mechanism (Buddemeier \& Oberdorfer 1989, Huettel et al. 2003), that may largely exceed transport by diffusion (Boudreau et al. 2001). Pore water advection is considered a major reason for high mineralization rates in permeable sediments (Webb \& Theodor 1968, Huettel \& Gust 1992, Shum \& Sundby 1996), providing oxygen and organic carbon from the water column to the benthic system, while removing potentially inhibitory end products of mineralization processes (Ziebis et al. 1996, Falter \& Sansone 2000, Rusch et al. 2000). Pore water advection is generated by pressure gradients across the sediment resulting from the interaction of currents or waves with uneven bedtopography (Buddemeier \& Oberdorfer 1989, Huettel \& Gust 1992, Precht \& Huettel 2003), or from density fluctuations (Webster et al. 1996). In coral reefs, tideinduced pressure gradients resulting from water level differences across the reef crest may cause a significant water flow through sediments and reef framework (Oberdorfer \& Buddemeier 1986, Parnell 1986).

The supply of oxygen to and its penetration depth into the sediments determines whether aerobic and anaerobic processes are dominant. Oxygen consumption, the sum of aerobic mineralization and oxygen consumption by reduced substances from anaerobic decay, increases with increasing advective supply of oxygen (Forster et al. 1996). Measurements of oxygen distribution in coral reef sediments are rare. King et al. (1990) measured an oxygen penetration depth of 0.5 to $1 \mathrm{~cm}$, and an oxygen penetration exceeding $1.5 \mathrm{~cm}$ when water movement was high. In sediments of another coral reef oxygen was reported to penetrate as deep as 15 to $50 \mathrm{~cm}$, which was attributed to wave action (Falter \& Sansone 2000). Deep oxygen penetration may support benthic aerobic and suboxic metabolism. In coral reef sediments, aerobic mineralization is dominant over anaerobic degradation (Boucher et al. 1994, Alongi 1998).

The dominant anaerobic mineralization process in most coastal marine sediments is sulfate reduction, typically responsible for up to $50 \%$ of the mineralization of organic matter (Jørgensen 1982, Canfield et al. 1993). Little is known about sulfate reduction in permeable sediments such as those in coral reefs. It is difficult to predict whether permeability enhances or limits sulfate reduction: advective transport from the water column supplies organic carbon to fuel sulfate reduction rates as well as oxygen that may lower sulfate reduction rates.

In order to evaluate the metabolic activity of sands, the choice of method is crucial. As the activity of permeable sands may be closely linked to pore water advection, the methods used to measure benthic activity should not block the local pore water advection (Buddemeier \& Oberdorfer 1989). Oxygen consumption rates (OCR) are used since the late 1960s as an integrating measure of sedimentary metabolism (Hargrave 1969). However, for the assessment of OCR, slurry incubations and flux calculations from pore water oxygen profiles are of limited use in sands, as they do not account for advective exchange. Stirred benthic chambers generate pressure gradients and pore water circulation patterns, resembling those generated by currents interacting with topography (Huettel \& Rusch 2000), however, intensive studies on local hydrodynamics and sediment topography are necessary in order to mimic natural pore water advection rates. To obtain oxygen consumption rates that account for pore water advection, we chose a recently introduced method that combines in situ time series of oxygen penetration depth measurements with laboratory measurements of volumetric sedimentary OCR (de Beer et al. 2005, Polerecky et al. 2005).

In this study, 1 focus was the in situ measurement of oxygen penetration and dynamics in the carbonate sediments of Heron Reef, Australia. A second focus was the determination of oxygen consumption, aerobic mineralization and sulfate reduction with methodological approaches that account for the effect of pore water advection. We selected 4 study sites with strongly different hydrodynamic regimes, to examine whether pore water advection is the main controlling parameter for benthic mineralization rates and to determine the ratio between aerobic and anaerobic mineralization.

\section{MATERIALS AND METHODS}

Study site. The study was carried out at Heron Island, Australia $\left(23^{\circ} 27^{\prime} \mathrm{S}, 151^{\circ} 55^{\prime} \mathrm{E}\right)$. The island is located in the lagoonal platform reef Heron Reef, on the southern boundary of the Great Barrier Reef (Fig. 1a). Average tidal range is $2 \mathrm{~m}$ at spring tide and $1 \mathrm{~m}$ at neap tide, with westerly currents during flood and easterly currents during the ebb tides. The average wind direction is SE. The mean annual air temperature is $24.1^{\circ} \mathrm{C}$ (T. Upton pers. comm.). Field experiments were conducted at 4 sublittoral stations (Fig. 1b). North Beach (NB), a shallow site exposed to strong currents, and Shark Bay (SB), a sheltered site exposed to weak currents, were located within the pseudolagoon close to the island. Here unconsolidated sediments occupy $78 \%$ of the surface area (calculated using unpublished data from A. Klueter) and corals form only small discrete patches. More remote from the island were the Reef Belt (RB) and the Channel (Ch) stations, where unconsolidated sediments occupy 

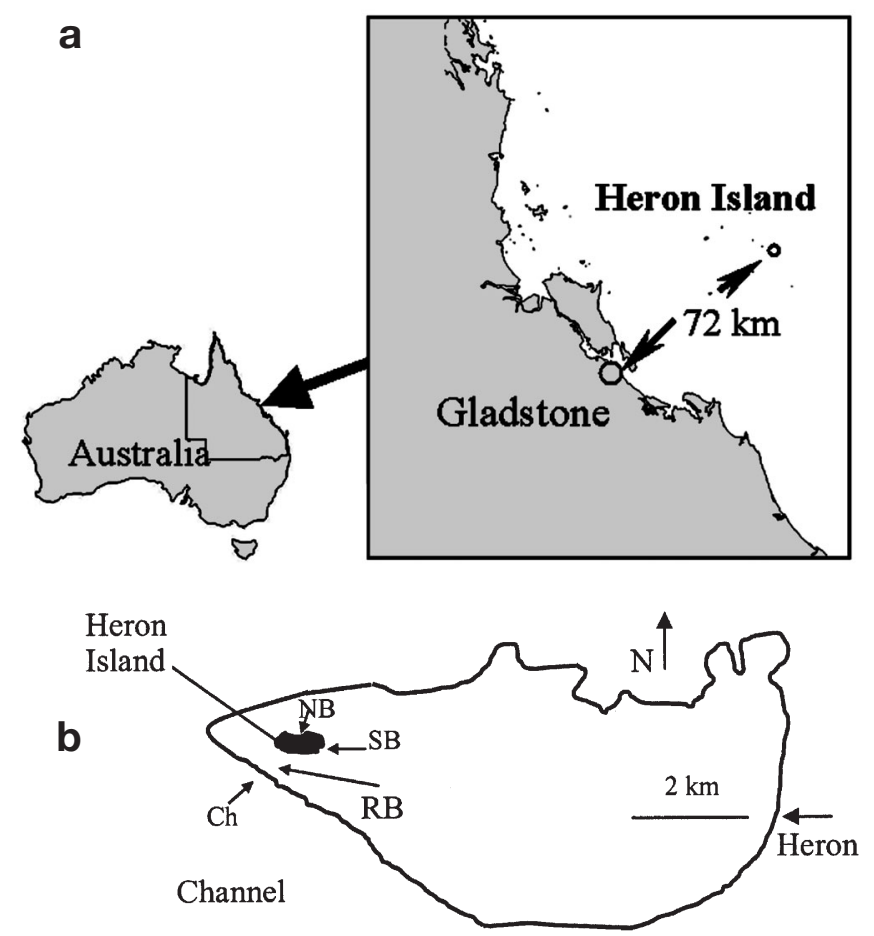

Fig. 1. Locations of (a) Heron Island and (b) the 4 sampling sites North Beach (NB), Shark Bay (SB), Reef Belt (RB) and Channel (Ch) at Heron Reef, Australia

$60 \%$ of the area and corals are almost continuous. Reef Belt was situated in the coral belt surrounding the pseudolagoon and was exposed to strong currents and breaking waves. The Channel station was located outside the reef platform, close to the reef edge in the channel between Heron Reef and Wistari Reef (water depth $5 \mathrm{~m}$ ); here currents were calm. The sediments at all stations consisted of carbonate sands of biogenic origin. North Beach and Shark Bay had the highest abundance of sediment mounds and burrows created by faunal organisms and careful digging revealed the highest numbers of macrofauna. Reef Belt had the lowest macrofaunal abundance. At all sites, we took care to sample areas with low abundances of faunal sediment structures (i.e. mounds and burrows). At Shark Bay, a large area inhabited by Callianassa sp. was found ca. $20 \mathrm{~m}$ distant from our sampling site.

Sampling. Most sampling and measurements were carried out in January 2002. During the sampling period seawater temperature varied between 27 and $33^{\circ} \mathrm{C}$ and salinity between 28 and 33. Sampling measurements were conducted within an area of $2 \mathrm{~m}^{2}$ at each site. Samples for analysis of sediment characteristics, oxygen consumption rates and sulfate reduction rates were collected with plastic cores (inner diameter $3.6 \mathrm{~cm}$ ). The sampling depth was usually $10 \mathrm{~cm}$, but in some cases was less than this due to buried rocks and compacted bottom sediment layers.
Sediment characteristics. Porosity and total organic carbon (TOC) content were determined in $1 \mathrm{~cm}$ subsections from 2 sediment cores per station. Samples for TOC were stored at $-20^{\circ} \mathrm{C}$ and freeze dried before analysis. [TOC] was determined by subtracting the total inorganic carbon [TIC] content from the total carbon [TC] content. TIC was measured by coulometric titration on a CM 5012 UIC coulometer. TC was measured using a Heraeus CHNO-rapid elemental analyzer with sulfanilamide as a calibration standard. Porosity was calculated from the weight loss of a known volume of wet sediment after drying at $60^{\circ} \mathrm{C}$ until constant weight was reached. Grain sizes were determined by sieving the pooled sediment of 2 cores through a calibrated sieve stack, and were classified according to Wentworth (1922).

Permeability of the upper $7 \mathrm{~cm}$ of the sediment was measured using the constant head method (Klute \& Dirksen 1986) on 2 replicate cores. The cores were stored frozen until analysis.

In situ oxygen distribution. In situ oxygen profiles were measured using Clark type oxygen microelectrodes (Revsbech 1989) with a tip diameter of $300 \mu \mathrm{m}$ to prevent damage by the coarse grains, an actual sensing area of $5 \mu \mathrm{m}$ diameter, and a response time $\left(t_{90}\right)$ of $<5 \mathrm{~s}$. The oxygen microsensors were mounted on an autonomous profiler as described by Glud et al. (1999) and Wenzhofer et al. (2000). The device was positioned on the sediment with the microsensors initially 1 to $2 \mathrm{~cm}$ above the sediment surface. Downward profiles were continuously measured over ca. $24 \mathrm{~h}$ to a sediment depth of $6 \mathrm{~cm}$, with a step size of $250 \mu \mathrm{m}$. Each profile was recorded within $30 \mathrm{~min}$, with a minimum pause of 5 min between profiles. At North Beach and Shark Bay, the $24 \mathrm{~h}$ measurements were repeated 3 times to assess longer scale temporal changes and assess reproducibility; at the other stations the $24 \mathrm{~h}$ cycles were run only once.

Oxygen consumption rates. Measurements of volumetric oxygen consumption rates were performed in the laboratory as described previously (de Beer et al. 2005, Polerecky et al. 2005). Experiments were conducted at $28^{\circ} \mathrm{C}$, the average in situ temperature of the sediments in January 2002. Oxygen microsensors were positioned at a defined depth within the sediment cores. Sediments were oxygenated by percolating ambient aerated seawater through the sediment cores until a steady state was reached at the depth of measurement. Then the percolation was stopped, and the decrease of oxygen over time was monitored. The initial concentration decrease was taken as the potential volumetric oxygen consumption rate (pOCR). The measurements were conducted in $2 \mathrm{~mm}$ steps within the first $1 \mathrm{~cm}$ of the sediment and in $0.5 \mathrm{~cm}$ steps between 1 and $4 \mathrm{~cm}$. We measured 2 replicate profiles 
per core and 2 cores per station. The measurements were performed in the dark to prevent photosynthesis.

The volumetric values obtained represent the potential oxygen consumption rates whenever oxygen is present at the specific sediment depth. To obtain the areal OCR of the sediments, the rates were integrated over the depths of oxygen penetration as obtained in situ from the profiler (for more details see de Beer et al. [2005] and Polerecky et al. [2005]). We assumed that OCR follow zero-order kinetics with respect to oxygen (Thamdrup et al. 1998).

Sulfate reduction rates. Sulfate reduction rates were measured with the whole core ${ }^{35} \mathrm{SO}_{4}{ }^{2-}$ radiotracer incubation method (Jørgensen 1978) modified for permeable sediments (de Beer et al. 2005). For each treatment, a minimum of 3 replicate sediment cores was incubated (incubation temperature $28^{\circ} \mathrm{C}$ ). Radiolabeled ${ }^{35} \mathrm{SO}_{4}{ }^{2-}$ (Amersham) was added to $70 \mathrm{ml}$ of ambient seawater to a specific activity of $340 \mathrm{MBq}$ per $\mathrm{mol} \mathrm{SO}_{4}{ }^{2-}$. The seawater-tracer solution was placed on top of the sediment and allowed to drain into the core. The permeability of the sediment allowed an even distribution of tracer in the pore water. After $6 \mathrm{~h}$ incubation (unless specified differently below), the sediments were frozen at $-20^{\circ} \mathrm{C}$. The frozen sediments were then sliced in $0.5 \mathrm{~cm}$ (0 to $3 \mathrm{~cm}$ depth) or $1 \mathrm{~cm}$ sections (below $3 \mathrm{~cm}$ ) and fixed in $20 \%$ ZnAc. Samples were processed using the cold chromium distillation procedure (Kallmeyer et al. 2004). The method was slightly modified by first adding $\mathrm{HCl}$ until all carbonates were dissolved. Radioactivity of ${ }^{35} \mathrm{SO}_{4}{ }^{2-}$ and total reduced inorganic sulfur (TRIS) was determined with a liquid scintillation counter (Packard 2500 TR), using Lumasafe Plus ${ }^{\circledR}$ (Lumac BV) scintillation cocktail. Pore water sulfate concentrations were determined by non-suppressed ion-chromatography and conductivity detection with a Waters 510 HPLC pump, Waters WISP 712 autosampler (100 $\mu \mathrm{l}$ injection volume), Waters IC-Pak anion exchange column $(50 \times 4.6 \mathrm{~mm})$ and a Waters 430 Conductivity detector. The eluant was $1 \mathrm{mM}$ isophthalate buffer in $10 \%$ methanol, adjusted to $\mathrm{pH} 4.5$ with sodium tetraborate.

In permeable sediments, the thus determined sulfate reduction rates may not be the in situ rates, as the supply of oxygen is restricted to molecular diffusion during incubation. In the field, oxygen penetrates much deeper into the sediments and may lower sulfate reduction rates, although this anaerobic process has been measured in oxidized and oxic sediments (Jørgensen 1977, Jørgensen \& Bak 1991). Because of the uncertainty about the inhibitory effects of oxygen, we made maximum and minimum estimations. The maximum sulfate reduction rates $\left(\mathrm{SRR}_{\max }\right)$ were not corrected for possible oxygen inhibition. To obtain minimum sulfate reduction rates $\left(\mathrm{SRR}_{\min }\right)$, i.e. assuming oxygen completely inhibits sulfate reduction, rates were integrated over the anoxic sediment depths only, as deduced from the in situ oxygen measurements.

Addition experiment: To asseses a possible limitation of SRR by organic matter, we added glucose $\left(2 \mathrm{mmol} \mathrm{l}^{-1}\right)$, acetate $\left(2 \mathrm{mmol} \mathrm{l}^{-1}\right)$ or fresh coral mucus $\left(0.72 \mathrm{mmol} \mathrm{C}^{-1}\right)$ to sediments cores taken from Shark Bay together with the seawater-tracer solution (3 replicates per treatment).

Influence of photosynthesis: To assess the effect of photosynthesis on sulfate reduction, we incubated sediments from North Beach and Shark Bay in the dark and under light (photosynthetically active radiation, PAR: $800 \mu \mathrm{mol}$ photons $\mathrm{m}^{-2} \mathrm{~s}^{-1}$; lamp: KL 1500 electronic, Schott). To assess the effect of a full light period, the incubation times were $12 \mathrm{~h}$ ( 3 replicates per treatment).

Silver foil technique: By trapping radiolabeled $\mathrm{H}_{2}{ }^{35} \mathrm{~S}$ on a silver foil as $\mathrm{Ag}^{35} \mathrm{~S}$, 2-dimensional images of $\mathrm{H}_{2}{ }^{35} \mathrm{~S}$ distribution were obtained (e.g. Krumholz et al. 1997, Visscher et al. 2000). Strips of silver foil $(30 \times 85 \mathrm{~mm}$ and $0.1 \mathrm{~mm}$ thick; Johnson Matthey $\mathrm{GmbH}$ ) were prepared as described in Krumholz et al. (1997). The silver foil was attached to the inner wall of cores before sampling sediments from North Beach and Shark Bay (4 replicates per station). The radiotracer incubation was then performed as described above and cores were incubated for 12 to $14 \mathrm{~h}$. After incubation the sediment cores were frozen, slightly thawed on the outside, and pushed out of the core liners, together with the foil. The foil was removed from the still frozen sediment, and washed with seawater to remove residual ${ }^{35} \mathrm{SO}_{4}{ }^{2-}$. The distribution of radioactivity of $\mathrm{Ag}^{35} \mathrm{~S}$ precipitates on the foils was analyzed using a phosphor imager (Phosphor imager SI, Molecular Dynamics). We assessed 3 profiles with a vertical data point resolution of $50 \mu \mathrm{m}$. For direct comparison with the silver foil data, the incubated sediments were further used for determination of SRR with the tracer whole core incubation method described above.

Aerobic mineralization rates. Oxygen consumption is the sum of aerobic mineralization and oxidation of reduced substances from anaerobic decay (e.g. $\mathrm{Fe}^{2+}$ and $\mathrm{H}_{2} \mathrm{~S}$ ). The sulfide produced during sulfate reduction is oxidized back to sulfate within the sediments, with oxygen as the ultimate electron acceptor. Therefore, areal aerobic mineralization rates were calculated by subtracting the SRR (expressed in equivalents of oxygen used for the oxidation of sulfides to sulfate) from the measured OCR. We assumed sulfate reduction to be the most important anaerobic respiration process, and the others were ignored. We also ignored burial of iron-sulfides, as iron concentrations in coral reef sediments are low (Alongi et al. 1996, Chambers et al. 2001).

Estimated bottom water filtration rates. The oxygen penetration depth is controlled by the balance between downward transport of oxygen and sedimentary OCR. Therefore, from the combined oxygen penetration depth 
and OCR data one can calculate the supply rate of oxygen to the sediment required to attain the measured oxygen penetration depth at the local OCR. From the supply rate of oxygen, one can further calculate the water volume that is pumped through the sediments (bottom water filtration rates in $1 \mathrm{~m}^{-2} \mathrm{~h}^{-1}$ ) by using the oxygen concentration in the overlying water, as summarized in the following formula (Polerecky et al. 2005):

$$
v_{\mathrm{f}}=\int_{0}^{z_{\mathrm{p}}} \mathrm{OCR}(z) \mathrm{d} z \times c_{0}^{-1}
$$

where $v_{\mathrm{f}}$ is the bottom water filtration rate in $1 \mathrm{~m}^{-2} \mathrm{~h}^{-1}$, $\int_{0}^{z_{\mathrm{p}}} \operatorname{OCR}(z) \mathrm{d} z$ is the oxygen consumption rates integrated over the oxygen penetration depth $\left(z_{\mathrm{p}}\right)$ in mmol $\mathrm{m}^{-2} \mathrm{~h}^{-1}$, and $c_{0}$ is the oxygen concentration in the overlying water in mmol $\mathrm{l}^{-1}$. This calculation is based on the simplifying assumption that the advective supply resembles a downward percolation. In reality, the water enters the sediment at the ripple troughs and flanks, and leaves the sediments near the ripple crest; thus, the flow of filtered water through sediments follows a curved path between in- and outflow areas (Huettel et al. 1996, Shum \& Sundby 1996). These horizontal components of the flow are ignored in the chosen approach, and the estimated bottom water filtration rates may thus underestimate natural pore water advection rates.

\section{RESULTS}

Sediment characteristics. Sediments at all stations were highly permeable (Table 1). Permeability was highest at Shark Bay, the North Beach and Reef Belt stations had similar permeability, and permeability at the Channel station was lowest (Table 1). North Beach and Shark Bay were composed of coarse sand, whereas the Reef Belt and Channel stations were composed of medium sands (medium and poorly sorted, respectively) according to Wentworth (1922). The grain content of the silt and clay size class was $<6 \%$ at the 3 reef platform stations (NB, SB and $\mathrm{RB}$ ) and $<11 \%$ at $\mathrm{Ch}$. Porosity was similar for the 3 platform stations and decreased with increasing depth at all stations.

The TOC content was low, constant with depth, and comparable at most stations. At North Beach the TOC content of the upper $3 \mathrm{~cm}$ was higher than at the other stations (Table 1).
Table 1. Sediment properties at North Beach (NB), Shark Bay (SB), Reef Belt (RB) and Channel stations (Ch). Except for grain size, data are averages \pm SD. TOC: total organic carbon.

$$
\text { -: no data }
$$

\begin{tabular}{|cccccc|}
\hline Stn & $\begin{array}{c}\text { Depth } \\
(\mathrm{cm})\end{array}$ & $\begin{array}{c}\text { Permeability } \\
\left(10^{-11} \mathrm{~m}^{2}\right)\end{array}$ & $\begin{array}{c}\text { Median grain } \\
\text { size }(\mu \mathrm{m})\end{array}$ & $\begin{array}{c}\text { Porosity } \\
(\%)\end{array}$ & $\begin{array}{c}\text { TOC } \\
(\% \text { dry wt })\end{array}$ \\
\hline $\mathrm{NB}$ & $0-7$ & $8.4 \pm 1.1$ & 591 & - & - \\
$\mathrm{NB}$ & $0-3$ & - & - & $66.8 \pm 4.7$ & $1.82 \pm 0.2$ \\
$\mathrm{NB}$ & $3-7$ & - & - & $55.8 \pm 3.5$ & $0.74 \pm 0.4$ \\
$\mathrm{SB}$ & $0-7$ & $13.6 \pm 0.2$ & 718 & $47.7 \pm 2.7$ & $0.50 \pm 0.3$ \\
$\mathrm{RB}$ & $0-7$ & $6.5 \pm 0.1$ & 426 & $54.6 \pm 0.9$ & $0.75 \pm 0.2$ \\
$\mathrm{Ch}$ & $0-7$ & $0.3 \pm 0.001$ & 227 & $64.5 \pm 1.0$ & $0.59 \pm 0.2$ \\
\hline
\end{tabular}

In situ oxygen distribution and dynamics. uring all measurements of in situ oxygen distribution, weather conditions were calm and comparable. Indeed, the 3 replicate measurements at North Beach and Shark Bay had a high reproducibility (Fig. 2). Oxygen dynamics and oxygen penetration depths differed between stations (Figs. 2 \& 3). At the North Beach and Reef Belt stations, oxygen penetrated deepest and oxygen dynamics were pronounced (Figs. 2 \& 4). At Reef Belt, breaking waves and strong currents lead to a dynamic seafloor topography and migrating ripples, therefore the oxygen penetration depth could not be determined for all profiles (Fig. 2). At the Shark Bay and Channel stations, the oxygen penetration depth was shallow and dynamics were weak (Figs. 2, 3 \& 5).

The in situ oxygen profiles in Fig. 6a show that photosynthesis and bioturbation can supply oxygen to the sediments. Photosynthesis caused the near surface oxygen peak, with concentrations above that of the

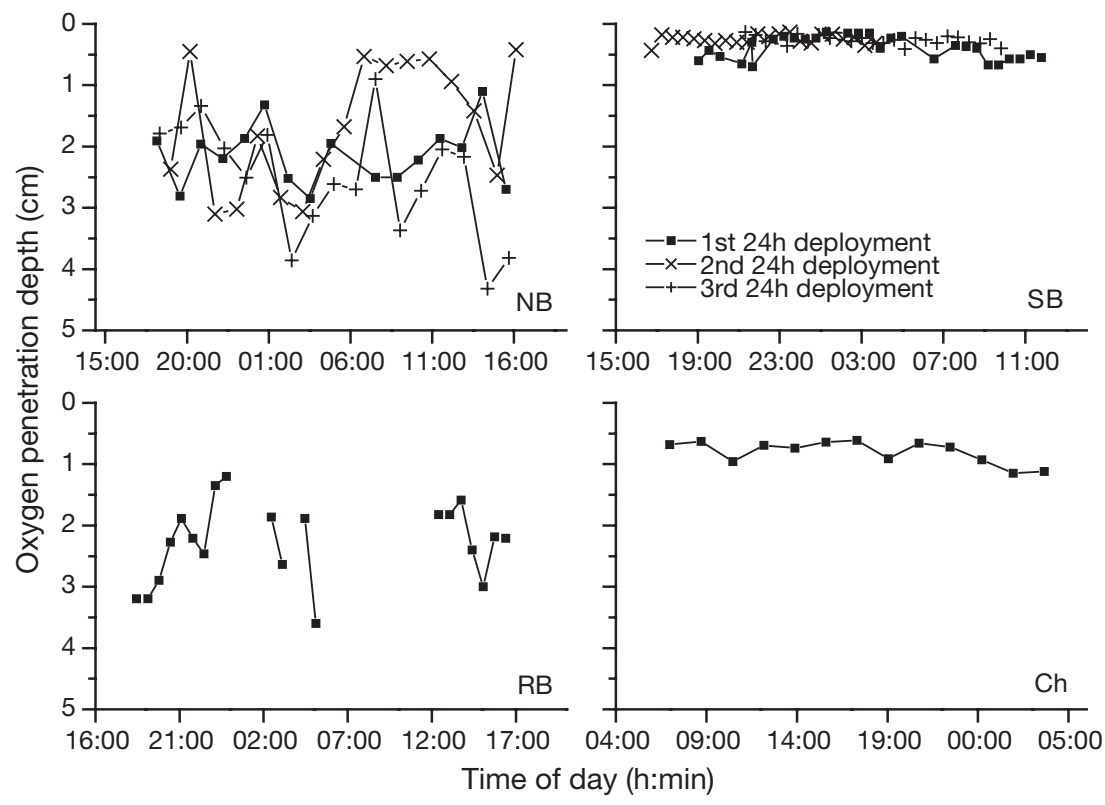

Fig. 2. Oxygen penetration depth at the 4 sampling sites. NB: North Beach; SB: Shark Bay; RB: Reef Belt; Ch: Channel station. 0: sediment surface 


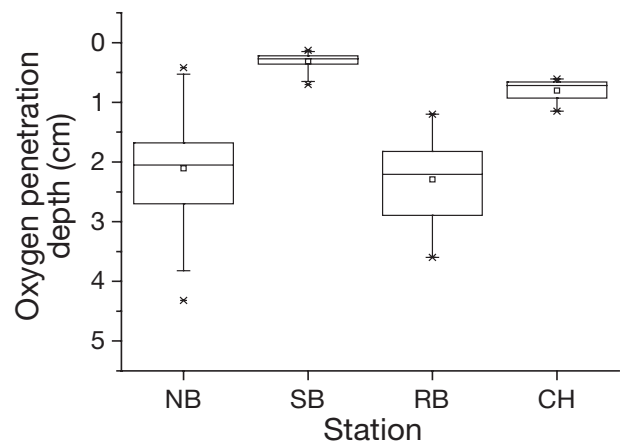

Fig. 3. Oxygen penetration depths at North Beach (NB), Shark Bay (SB), Reef Belt (RB) and Channel (Ch) stations. Horizontal lines (top, middle, bottom of boxes) represent 25th, 50th (median) and 75th percentiles; error bars represent 5th and 95th percentiles. Symbols below and above error bar denote extreme values; square symbols inside boxes: average values overlaying water. Bioturbation may have caused the deeper ephemeral oxygen peak. Fig. 6b shows a pore water advection dominated, rather sigmoid shaped oxygen profile (Revsbech et al. 1980) measured in situ, with a deep oxygen penetration and a constant oxygen concentration in the upper $2.7 \mathrm{~cm}$. In contrast, the diffusion dominated oxygen profile measured in the laboratory (Fig. 6b), shows shallow oxygen penetration and the nearly parabolic shape of diffusion dominated profiles.

Oxygen consumption rates. The highest pOCR (above the maximal oxygen penetration depth) were measured at the Channel station (Fig. 7). The 2 stations close to Heron Island (NB and SB) had intermediate and similar pOCR, whereas Reef Belt had the lowest pOCR.

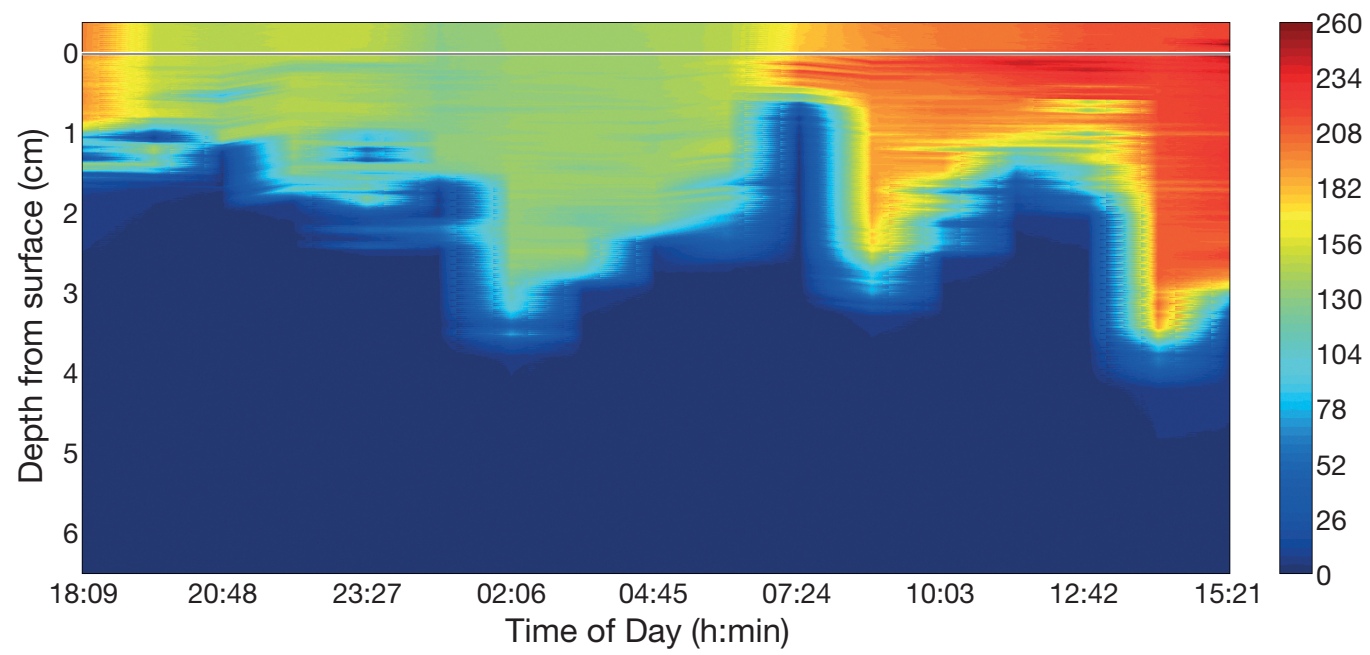

Fig. 4. Time series of oxygen profiles at North Beach showing measurements over $1 \mathrm{~d}$. Color scale: oxygen concentration $\left(\mu \mathrm{mol} \mathrm{l}^{-1}\right)$. Horizontal line at zero represents sediment surface. Note that oxygen saturation is approx. $200 \mu \mathrm{mol} \mathrm{l}^{-1}$, indicating oxygen oversaturation of overlying water and upper sediment layers during the daytime

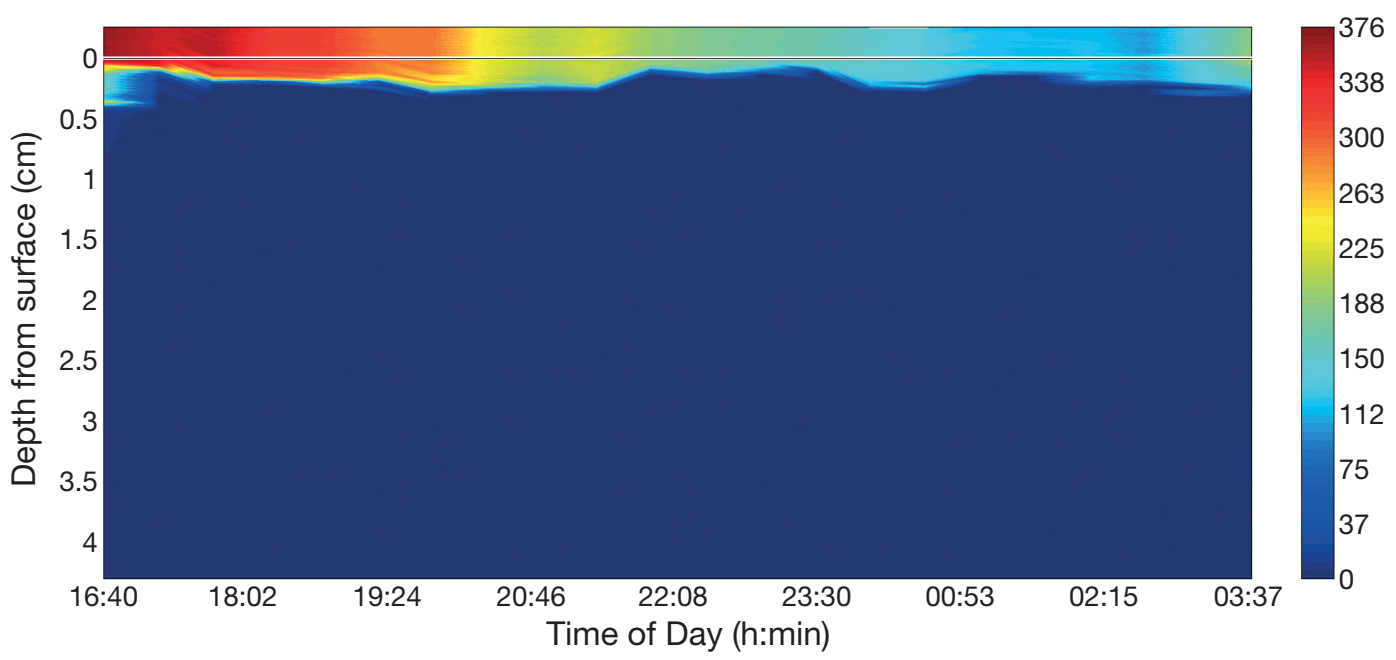

Fig. 5. Time series of oxygen profiles at Shark Bay. Further details as for Fig. 4 


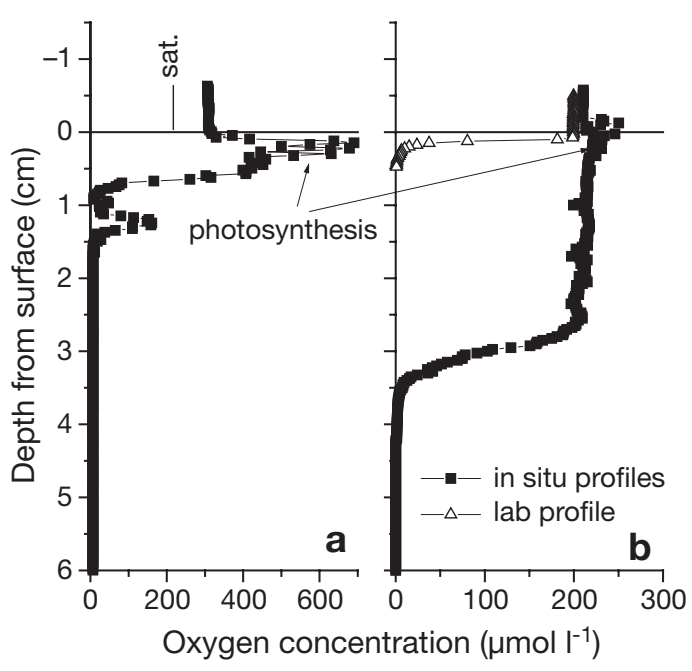

Fig. 6. Examples of oxygen concentration profiles measured at North Beach. Oxygen production by benthic photosynthesis is indicated. Deep oxygen peak in (a) may result from faunal pumping activity. For comparison of pore water advection and diffusion dominated oxygen profiles, a diffusive laboratory (lab) profile is shown in (b). sat: saturation of oxygen at ambient temperature and salinity

The areal OCR (Fig. 8, Table 2) are obtained by integrating the pOCR over the varying oxygen penetration depths. Although pOCR were comparable at North Beach and Shark Bay, the different oxygen penetration at these stations resulted in different areal OCR. The areal OCR at the North Beach (with its deep oxygen penetration) and Channel (with its shallow oxygen penetration) stations were comparable; thus

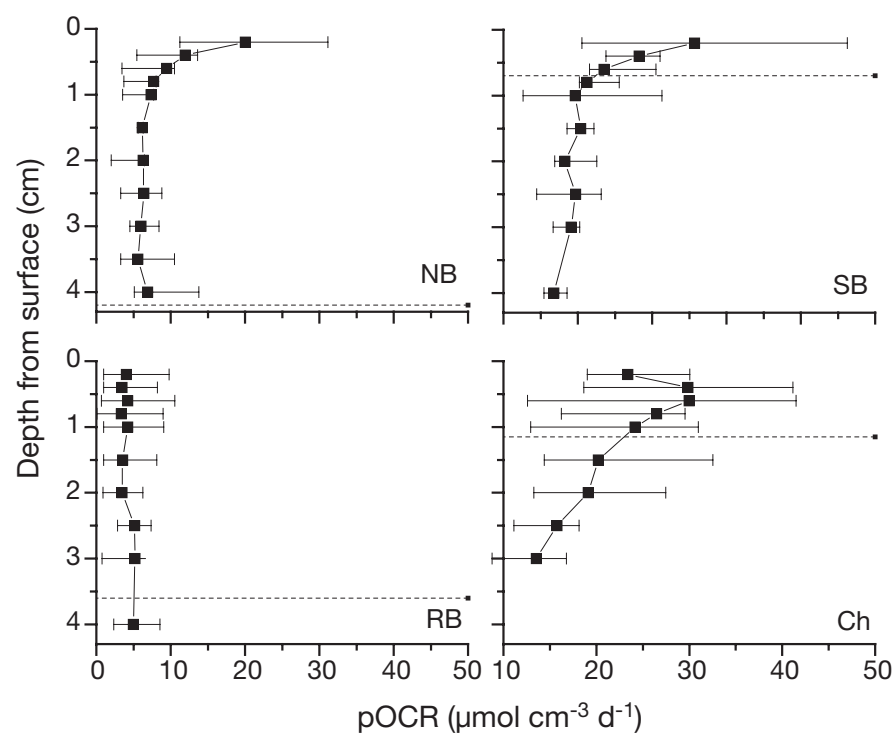

Fig. 7. Median volumetric oxygen consumption rates (pOCR) at all 4 sampling sites (abbreviations as in Fig. 1) Error bars for volumetric oxygen consumption rates indicate measured data range, dashed line indicates maximum oxygen penetration depth

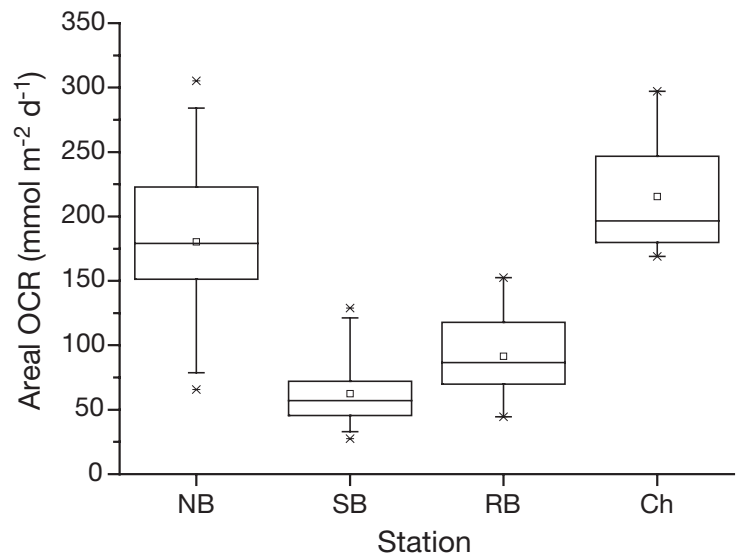

Fig. 8. Areal oxygen consumption rates (OCR) at North Beach (NB), Shark Bay (SB), Reef Belt (RB) and Channel (CH) stations. Further details as for Fig. 3

the deep oxygen penetration compensated for lower volumetric activities. At Reef Belt station, areal OCR were intermediate.

Sulfate reduction rates. Sulfate concentrations were in the range of 28 to $30 \mathrm{mmol} \mathrm{l}^{-1}$ and did not vary with depth or between stations. Volumetric SRR (Fig. 9) at all sites were highest in the upper 2 to $3 \mathrm{~cm}$ of the sediment. Depth integrated SRR varied between sites (Table 2), with highest potential sulfate reduction rates $\left(\mathrm{SRR}_{\max }\right)$ at North Beach and Shark Bay. The Channel station had intermediate $\mathrm{SRR}_{\max }$, whereas Reef Belt had the lowest $\mathrm{SRR}_{\max }$ of all stations. The minimum estimate of the sulfate reduction rates $\left(\mathrm{SRR}_{\min }\right)$ differed from $S_{R} R_{\max }$ especially at those stations with deep oxygen penetration (North Beach and Reef Belt stations) (Table 2). The relative contribution of sulfate reduction to total mineralization (Table 2) varied between sites. At most stations anaerobic mineralization contributed 10 to $20 \%$, only in Shark Bay was most organic matter mineralized anaerobically.

Aerobic mineralization rates. The pattern of aerobic mineralization rates (Table 2) was comparable to that of areal OCR, with high rates at the North Beach and Channel stations, intermediate rates at Reef Belt and low rates at Shark Bay.

OCR and SRR were repeatedly measured in August 2003 (data not shown) at all stations except the Channel station, and similar volumetric rates and comparable trends were found.

SRR in response to organic carbon addition. The ad-

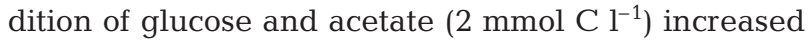
SRR at all depths, indicating a limitation of SRR by dissolved organic carbon. Surprisingly, the addition of fresh, homogenized coral mucus $(0.72 \pm 0.03 \mathrm{mmol}$ $\mathrm{C}^{-1}$ ) did not increase, but decreased SRR (Fig. 10).

Effect of light on SRR. Illumination did not affect SRR (data not shown). Thus, photosynthetically produced 
organic substances or oxygen did not have a detectable effect on SRR over the $12 \mathrm{~h}$ period.

$\mathrm{H}_{2} \mathrm{~S}$ production measurement by the silver foil technique. The variability among the 3 replicate profiles of $\mathrm{Ag}^{35} \mathrm{~S}$ measured by silver foil was small and the shapes of the replicate profiles per foil were similar with depth for all cores from North Beach and Shark Bay (Fig. 11). However, in 7 out of 8 data sets, the depth distribution of radioactive $\mathrm{H}_{2} \mathrm{~S}$ trapped on the silver foil showed no agreement with the depth distribution of SRR measured with the tracer whole core incubation method on the same core (Fig. 11).

Estimated bottom water filtration rates. Estimated bottom water filtration rates were similar at the North Beach and Channel stations (NB median $=33 \mathrm{l} \mathrm{m}^{-2} \mathrm{~h}^{-1}$, range 4 to $70 \mathrm{l} \mathrm{m}^{-2} \mathrm{~h}^{-1}$; Ch median $=34 \mathrm{l} \mathrm{m}^{-2} \mathrm{~h}^{-1}$, range 20 to $62 \mathrm{l} \mathrm{m}^{-2} \mathrm{~h}^{-1}$ ). Pore water advection rates at the Shark Bay and Reef Belt stations were lower (SB median $=10 \mathrm{l} \mathrm{m}^{-2} \mathrm{~h}^{-1}$, range 3 to $30 \mathrm{l} \mathrm{m}^{-2} \mathrm{~h}^{-1}$; RB median $=12 \mathrm{l} \mathrm{m}^{-2} \mathrm{~h}^{-1}$, range 3 to $53 \mathrm{l} \mathrm{m}^{-2} \mathrm{~h}^{-1}$ ).

\section{DISCUSSION}

\section{Oxygen distribution}

At all stations, pore water advection was a major factor in the transport of oxygen into the sediments, as evidence by the sigmoid shape of the oxygen profiles and the deep and variable in situ oxygen penetration depths compared to diffusion controlled laboratory experiments (oxygen penetration depth $<3 \mathrm{~mm}$, data not shown).

Oxygen penetration and dynamics differed between sites. Oxygen penetrated deep and dynamically at 2 exposed sites (North Beach and Reef Belt stations), whereas at the more sheltered stations (Shark Bay and Channel) oxygen penetration was shallow and uniform. The sequence for oxygen penetration depths at the 4 stations can be summarized as $\mathrm{NB}=\mathrm{RB}>\mathrm{Ch}>$

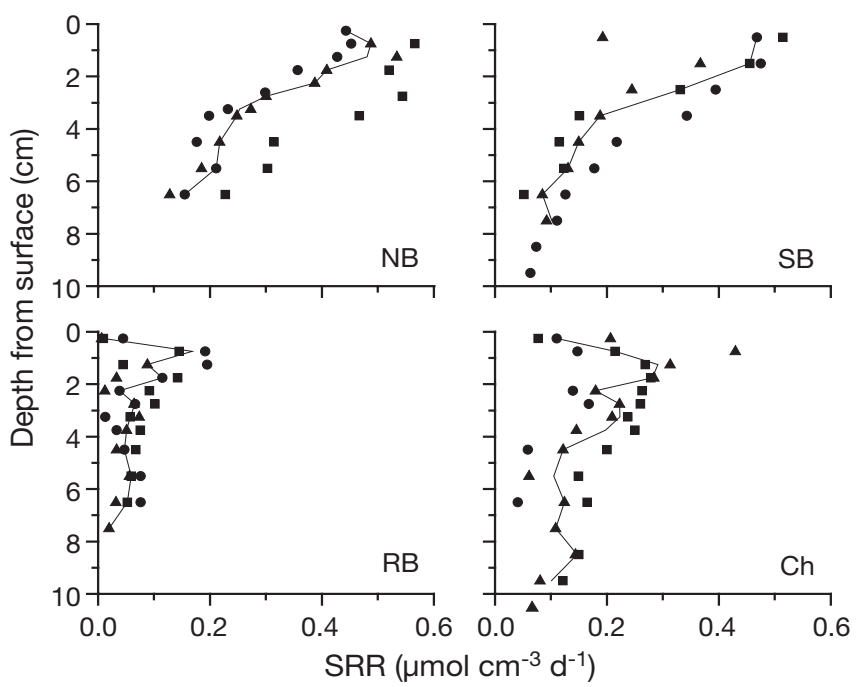

Fig. 9. Sulfate reduction rates (SRR) at North Beach (NB), Shark Bay (SB), Reef Belt (RB) and Channel (Ch) stations. $(\bullet, \square, \boldsymbol{\Lambda})$ Replicate measurements; black line: median of data set

SB. The composition of the sediment at all stations was typical of permeable sediments. There was, however, no correlation between oxygen penetration depth and permeability. For example, Shark Bay had the highest permeability but the lowest oxygen penetration depths. The differences in oxygen penetration and dynamics may thus to a large extent be explained by differences in local hydrodynamics. The deep and variable oxygen penetration at the North Beach and Reef Belt stations reflected fast and pronounced oxygenation and de-oxygenation caused by the strong and variable bottom currents and by wave action. Additionally, the local hydrodynamics led to migrating rugosity elements (e.g. ripples) at these stations. The pressure gradients developing around these topographical structures resulted in migrating zones of down and upwelling pore water (Huettel \& Gust 1992, Precht et al. 2004), contributing to the alterations in

Table 2. Areal oxygen consumption rates (OCR), estimated areal aerobic mineralization (Aer. min), maximum and minimum depth integrated sulfate reduction rates $\left(\mathrm{SRR}_{\max }\right.$ and $\mathrm{SRR}_{\min }$, respectively) $\left(\mathrm{mmol} \mathrm{C} \mathrm{m}^{-2} \mathrm{~d}^{-1}\right)$, and contribution of sulfate reduction to total carbon mineralization (\% contrib). First value for estimated aerobic mineralization is based on OCR and $\mathrm{SRR}_{\max }$, second value on OCR and $S_{R R}$ mini first value for contribution of SRR to total carbon mineralization is based on $\mathrm{SRR}_{\min }$, second value on $\mathrm{SRR}_{\max }$. Integration depth for $\mathrm{SRR}$ is $7 \mathrm{~cm}$. Data are median (range in parentheses)

\begin{tabular}{|cccccc|}
\hline Stn & OCR & Aer. min & SRR $_{\max }$ & $\mathrm{SRR}_{\min }$ & \% contrib. \\
\hline NB & $183.5(66-305)$ & $142-160$ & $41.8(38-58)$ & $23.2(19-40)$ & $15-27$ \\
SB & $57.1(27-129)$ & $21-24$ & $36.1(26-44)$ & $33.4(23-41)$ & $69-74$ \\
RB & $88.2(44-153)$ & $79-83$ & $9.1(6-11)$ & $5.4(2-7)$ & $6-10$ \\
Ch & $196.6(169-297)$ & $173-176$ & $24.2(20-28)$ & $20.8(17-25)$ & $12-14$ \\
\hline
\end{tabular}
oxygen penetration depths. The shallower and more uniform oxygen penetration at the Shark Bay and Channel stations reflected more stationary pressure gradients, perhaps occasioned by weaker hydrodynamics or more stationary sediment topography. At the Channel station, the effect of surface gravity waves on advective exchange could be smaller than at the other stations because of its deeper water depth; at Shark Bay, the development of microalgal mats was observed when currents were calm. Less turbulent hydrodynamics may lower resuspen- 


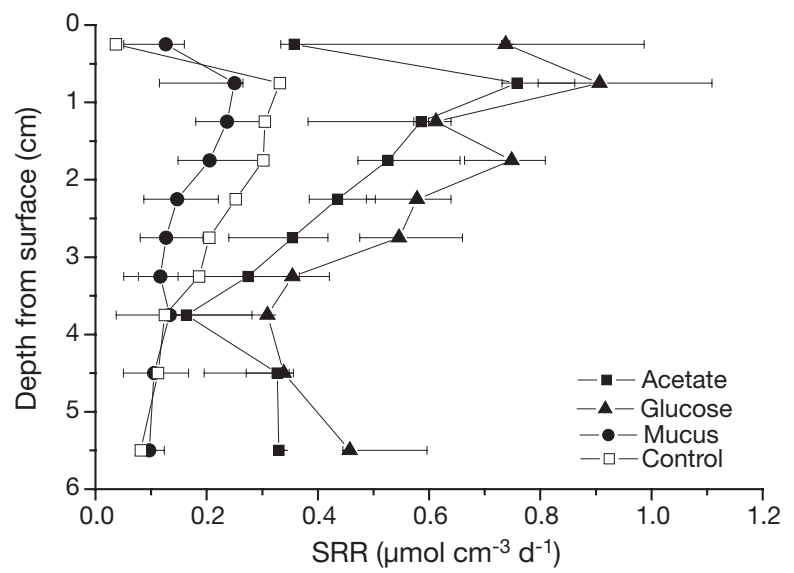

Fig. 10. Median sulfate reduction rates (SRR) after addition of glucose, acetate and homogenized coral mucus and control. Error bars represent data range

sion, and thus favor the development of microalgal mats (Demers et al. 1987) that may temporarily decrease sediment permeability. Benthic photosynthesis supplied oxygen to the top sediment layers, often causing oxygen oversaturation; however, there was no obvious increase in oxygen penetration depth caused by benthic photosynthesis. Our data do not indicate variable oxygen penetration due to tide-induced pres- sure gradients across the reef crest (Oberdorfer \& Buddemeier 1986, Parnell 1986).

The sequence of estimated bottom water filtration rates according to Eq. (1) is $\mathrm{Ch}=\mathrm{NB}>\mathrm{RB}=\mathrm{SB}_{\text {; the }}$ North Beach and Reef Belt stations (whose sediment topography is fairly similar) thus have similar oxygen penetration depths but distinctly different pore water advection rates. The pore water advection rate was high at the Channel station, perhaps because of specific topography or acceleration of bottom water currents between coral patches. The bottom water filtration rates are only estimates, since the horizontal components of the pressure gradient driven flow of water through the sediments were not considered.

\section{Benthic mineralization rates}

Pore water advection is considered the major factor responsible for high mineralization rates in permeable sediments: bottom water entering the sediment transports oxygen to the deeper sediment layers, which filter organic matter from the water (Webb \& Theodor 1968, Pamatmat 1971, Huettel \& Gust 1992, Shum \& Sundby 1996). The method of OCR assessment used in the present study enables differentiation between volumetric and areal OCR as it is possible for SRR. The

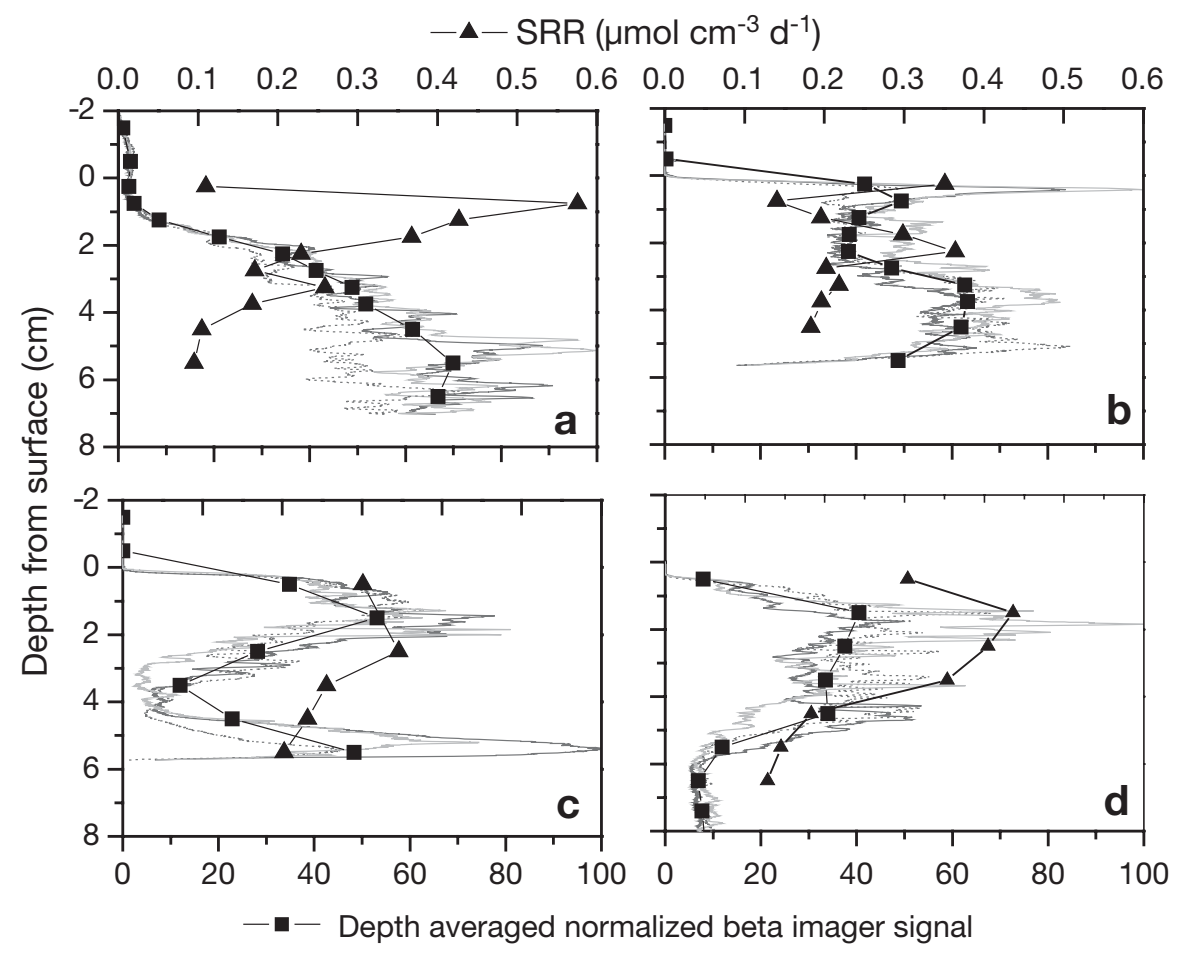

Fig. 11. Comparison of normalized beta imager signal of $\mathrm{Ag}^{35} \mathrm{~S}$ on silver foil, and sulfate reduction rates obtained with tracer whole core incubation method for 4 representative sediment cores. Gray lines: 3 distinct beta imager signal profiles measured with silver

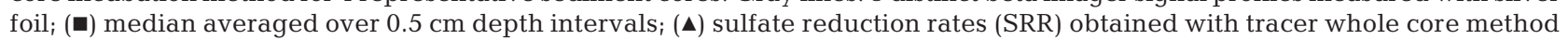


sequence for volumetric OCR (in the oxygenated sediment layers) is $\mathrm{Ch}>\mathrm{NB}=\mathrm{SB}>\mathrm{RB}$ and for sulfate reduction is $\mathrm{NB}=\mathrm{SB}>\mathrm{Ch}>\mathrm{RB}$. Thus, the pattern of volumetric OCR and SRR between sites is not related to the estimated pore water advection rates. Volumetric OCR and SRR at North Beach and Shark Bay are, for example, similar, although their pore water advection rates differ. The volumetric mineralization rates represent the turnover potential at a specific site resulting from the activity, size and composition of the local benthic assemblages. High volumetric mineralization rates arise from beneficial environmental conditions for benthic organisms (e.g. supply of oxygen and organic carbon). Thus, factors other than pore water advection must be mainly responsible for the observed pattern and magnitude of volumetric mineralization rates. To determine the role of pore water advection in the magnitude and pattern of mineralization rates, one has to distinguish between the advective supply of oxygen and the advective supply of organic matter in the water column. The supply of oxygen by pore water advection is of major importance to the magnitude of mineralization rates at our sites, as it fuels the high aerobic mineralization rates. The volumetric OCR were at least 1 order of magnitude higher than the volumetric SRR, indicating a high contribution of aerobic mineralization to total mineralization at all depths within the oxygenated sediment layer Additionally, the advective supply of oxygen to the sediments is a major determinant of the oxygen penetration depth, and thus determines the degree to which the potential aerobic mineralization can actually be realized (i.e. determines the magnitude of the areal OCR).

The availability of easily degradable organic carbon is a major factor determining benthic mineralization rates. However, the filtration of organic carbon from the water column by pore water advection seems to be of secondary importance to the magnitude and pattern of mineralization rates. The deviating pattern of volumetric mineralization rates and pore water advection rates may be due to other organic carbon sources, such as benthic photosynthesis or transport of organic matter to the sediments by fauna. High biomasses of meio- and macrofauna have been found in coral reef sediments (Wilkinson 1987, Riddle et al. 1990), and benthic animals are known to contribute to the particulate and solute fluxes across the sediment-water interface and within sediments (Graf \& Rosenberg 1997, Kristensen 2000). The presence of burrow-building, bioirrigating fauna, i.e. filter-feeding organisms, increases the solute exchange: the potential effective exchange area of the visible sediment surface is increased by the additional surfaces of their burrows walls within the sediment (Aller 2001). This influences the pathways and magnitude of benthic mineralization processes (Aller \& Aller 1998, Banta et al. 1999). Bioturbation can change sediment composition and increase sediment surface microtopography, thus having a significant impact on the exchange rates of oxygen and organic matter (Krantzberg 1985, Ziebis et al. 1996). Deposition of particles by animal constructions (e.g. mounds and burrows) and the feeding behavior of demersal plankton and fishes (e.g. Bishop \& Greenwood 1994, Marnane \& Bellwood 2002) are also important mechanisms for transporting organic matter to the sediments. A short distance from our sampling site in Shark Bay, we found large numbers of mounds built by the mud shrimp Callianassa sp. These structures have been shown to increase advective transport compared to sediments with a smooth surface (Ziebis et al. 1996). The distribution patterns of benthic fauna and their activities were beyond the scope of this study, but in the top 10 to $15 \mathrm{~cm}$ of the sediments, large numbers of sediment dwelling worms, shrimps, bivalves were present at North Beach, but far fewer were found at Reef Belt. It may be speculated that the low mineralization rates in Reef Belt may be a consequence of physical stress induced by intense water and sediment movement, making it an unfavorable site for infauna (Hall 1994). Conversely, steadier hydrodynamics in the Channel station may be favorable for benthic filter feeders and a refuge for defecating fishes. Thus the high aerobic mineralization rates compared to the moderate SRR at the Channel station may be due to a high contribution of respiring meio- and macrofauna to oxygen uptake.

High volumetric OCR and SRR were measured close to Heron Island, and may have resulted from a higher supply of organic carbon at these stations. At Shark Bay, high benthic primary production rates of $165 \mathrm{mmol} \mathrm{m}^{-2} \mathrm{~d}^{-1}$ were measured (Rasheed et al. 2004). King et al. (1990) suggested that close coupling between benthic algal production and heterotrophic metabolism may be a factor controlling SRR in coral reef sediments. However, we did not observe a response of SRR to light in North Beach and Shark Bay sediments. Inhibition of SRR or photosynthetically produced oxygen may have compensated a positive stimulation by excreted or produced organic carbon. An important carbon source around the island is coral mucus. Coral mucus (considered an energy carrier and planktonic particle trap in coral reefs) is concentrated by tidal currents in the lagoon around Heron Island, where it sediments to the seafloor, leading to enhancement of benthic mineralization processes (Wild et al. 2004a). Additionally, sedimentary processes at North Beach and Shark Bay may be enhanced by terrestrial input from the island (Smith \& Johnson 1995). 


\section{Role of sulfate reduction}

Although SRR were high, aerobic mineralization dominated sediment mineralization processes at most sites, as found in previous studies (Boucher et al. 1994, Alongi 1998). Sulfate reduction may be dominant in some areas within the reef, such as in Shark Bay, where local pore water advection was low and sediment oxygenation restricted to a few millimeters. SRR were limited by organic carbon, as the addition of dissolved glucose and acetate led to an enhancement of SRR. Interestingly, fresh coral mucus did not increase SRR. This could indicate that fresh mucus is not a suitable energy source for sulfate reducing bacteria, but might well be due to cytotoxic substances that occur in freshly released coral mucus (Fung et al. 1997). Inhibition of SRR by antimicrobial substances in fresh mucus has not yet been reported and may deserve more detailed investigations. The SRR measured in sediment cores $6 \mathrm{~h}$ after mucus exposure were elevated (Wild et al. 2004b). Thus, with time and exposure to degradation processes, coral mucus may become an appropriate electron donor for sulfate reducing bacteria.

The sulfide produced during sulfate reduction can, in both dissolved and iron-bound form, be oxidized to sulfate through a complex series of processes (e.g. Jørgensen 1990). Sulfide oxidation processes are likely to play an important role at the investigation sites. Sulfide oxidation may explain the differences in $\mathrm{Ag}^{35} \mathrm{~S}$ distribution obtained with the silver foil technique and the SRR obtained with the tracer whole core method. Not all of the sulfide produced by sulfate reduction was necessarily bound to silver foil. Only free sulfide reacts with silver, whereas the chromium distillation method detects all major inorganic sulfur compounds (e.g. $\mathrm{H}_{2} \mathrm{~S}$, FeS, $\mathrm{FeS}_{2}, \mathrm{~S}_{8}, \mathrm{~S}_{2} \mathrm{O}_{3}{ }^{2-}$ ), excluding sulfate (Kallmeyer et al. 2004). Rapid oxidation of sulfide (or in iron-rich environments, a rapid precipitation of iron sulfides) thus prevents efficient trapping of sulfides by silver foil. These are drawbacks of the silver foil technique when used for the quantitative assessment of sedimentary SRR. Additionally, the 2 techniques integrate over different sediment volumes, which could have contributed to the differences. In combination with the tracer whole core incubation method, the silver foil technique can be used to reveal zones of sedimentary sulfide oxidation and binding; however, it has to be borne in mind, that unknown processes may influence to the results.

\section{Comparison of oxygen penetration and mineralization rates in the literature}

In situ measurements of oxygen distribution within coral reef sediments are rare. The comparably low oxy- gen penetration depths measured at the Shark Bay and Channel station were similar to in situ oxygen data of King et al. (1990), who measured an oxygen penetration exceeding $15 \mathrm{~mm}$ only during a period of high water movement. Entsch et al. (1983) and Williams et al. (1985) measured reducing conditions below $5 \mathrm{~cm}$ with redox electrodes, indicating permanent anoxia below this sediment depth. In contrast to these and our results, Falter \& Sansone (2000) measured an oxygen penetration of 15 to $50 \mathrm{~cm}$ in pore water samples taken from well points; they attributed this deep oxygen penetration to wave induced pore water advection.

The areal OCR measured at the North Beach and Channel stations are, to our knowledge, among the highest reported for carbonate reef sediments. This may be due to the method used, as the OCR measured in this paper took into consideration the relationship of oxygen penetration depth to hydrodynamics. At a temperate sandflat, the OCR measured with this method were twice as high as that measured in stirred benthic chambers (de Beer et al. 2005). However, whether these 2 methods result in different OCR may depend largely on the currents speed in the specific area. This might explain why in the sheltered Shark Bay, measurements carried out simultaneously with stirred benthic chambers in January 2002 (Wild et al. 2004b) and previous measurements (Rasheed et al. 2004) with stirred benthic chambers, revealed OCR comparable to our measured rates. The rates obtained for Shark Bay and Reef Belt stations are comparable to rates found in other coral reef sediments (Boucher et al. 1994, Clavier \& Garrigue 1999, Grenz et al. 2003)

The high SRR measured at the 2 stations close to Heron Island (NB and SB) are comparable only to SRR measured in carbonate reef sediments surrounded by mangroves (Hines \& Lyons 1982) or highly influenced by terrigenious input (King et al. 1990). The SRR measured in the Reef Belt and Channel stations were as low as those reported previously for coral sands (Skyring \& Chambers 1976, Skyring 1985, Nedwell \& Blackburn 1987, King et al. 1990, Alongi et al. 1996). However, comparison of SRR with previous investigations is limited, as methods used before 1985 may have underestimated SRR by underestimating the chromium reducible sulfur pool (CRS, mainly $\mathrm{S}^{0}$ and $\mathrm{FeS}_{2}$ ).

\section{Importance of sediments to reef ecosystem}

The high aerobic and anaerobic mineralization rates recorded confirmed that reef sediments can be very active and contribute significantly to element cycling within the reef ecosystem. The heterogeneity of the reef system makes an extrapolation of our data to the Heron Island lagoon weak. However, if the 3 reef plat- 
form stations are considered representative of the reef area around Heron Island, then the sediment turnover would be between approx. 500 and $1800 \mathrm{~kg} \mathrm{C} \mathrm{km}-2$ $\mathrm{d}^{-1}$. A rough estimate of the turnover rates for the total area of Heron Reef occupied by sediments (sediment area $=19.5 \mathrm{~km}^{2}$ ) would be in the order of 3700000 to $13000000 \mathrm{~kg} \mathrm{C} \mathrm{a}^{-1}$ (ignoring seasonal differences).

Acknowledgements. We thank all technicians from the microsensor group for constructing the excellent microsensors. The people from HIRS are thanked for their logistic help and hospitality. We thank C. Schoenberg and E. Walpersdorf for taking and shipping samples. We thank B. B. Jørgensen, M. Huettel and H. Røy for very helpful discussions and support. This study was financed by the Max Planck Society (MPG), Germany.

\section{LITERATURE CITED}

Aller RC (2001) Transport and reactions in the bioirrgated zone. In: Boudreau BP, Jørgensen BB (eds) The benthic boundary layer: Transport processes and biogeochemistry. Oxford University Press, Oxford, p 269-301

Aller RC, Aller JY (1998) The effect of biogenic irrigation intensity and solute exchange on diagenetic reaction rates in marine sediments. J Mar Res 56:905-936

Alongi DM (1998) Coastal ecosystem processes. CRC Press, Boca Raton, FL

Alongi DM, Tirendi F, Goldrick A (1996) Organic matter oxidation and sediment chemistry in mixed terrigenouscarbonate sands of Ningaloo Reef, Western Australia. Mar Chem 54:203-219

Andrews JC, Hans M (1983) Space-time variability of nutrients in a lagoonal patch reef. Limnol Oceanogr 28: 215-227

Banta GT, Holmer M, Jensen MH, Kristensen E (1999) Effects of two polychaete worms, Nereis diversicolor and Arenicola marina, on aerobic and anaerobic decomposition in a sandy marine sediment. Aquat Microb Ecol 19:189-204

Bishop JW, Greenwood JG (1994) Nitrogen-excretion by some demersal macrozooplankton in Heron and One-Tree Reefs, Great Barrier Reef, Australia. Mar Biol 120:447-453

Boucher G, Clavier J, Garrigue C (1994) Oxygen and carbondioxide fluxes at the water-sediment interface of a tropical lagoon. Mar Ecol Prog Ser 107:185-193

Boudreau B, Huettel M, Forster R, Jahnke A and 10 others (2001) Permeable marine sediments: overturning an old paradigm. EOS Trans Am Geophys Un 82:133-136

Buddemeier R, Oberdorfer J (1989) Hydrogeology and hydrodynamics of coral reef pore waters. Proc 6th Int Coral Reef Symp 2:485-490

Canfield DE, Thamdrup B, Hansen JW (1993) The anaerobic degradation of organic-matter in danish coastal sediments -iron reduction, manganese reduction, and sulfate reduction. Geochim Cosmochim Acta 57:3867-3883

Capone DG, Dunham SE, Horrigan SG, Duguay LE (1992) Microbial nitrogen transformations in unconsolidated coral-reef sediments. Mar Ecol Prog Ser 80:75-88

Chambers RA, Fourqurean JW, Macko SA, Hoppenot R (2001) Biogeochemical effects of iron availability on primary producers in a shallow marine carbonate environment. Limnol Oceanogr 46:1278-1286

Clavier J, Garrigue C (1999) Annual sediment primary pro- duction and respiration in a large coral reef lagoon (SW New Caledonia). Mar Ecol Prog Ser 191:79-89

Crossland CJ, Barnes DJ (1983) Dissolved nutrients and organic particulates in water flowing over coral reefs at Lizard-Island. Aust J Mar Freshw Res 34:835-844

de Beer D, Wenzhoefer F, Ferdelman TG, Boehme SE and 5 others (2005) Transport and mineralization rates in North Sea sandy intertidal sediments, Sylt-Rømø Basin, Wadden Sea. Limnol Oceanogr 50:113-127

Demers S, Therriault JC, Bourget E, Bah A (1987) Resuspension in the shallow sublittoral zone of a macrotidal estuarine environment-wind influence. Limnol Oceanogr 32: $327-339$

Enos P, Sawatsky LH (1981) Pore networks in Holocene carbonate sediments. J Sediment Petrol 51:961-985

Entsch B, Boto KG, Sim RG, Wellington JT (1983) Phosphorus and nitrogen in coral-reef sediments. Limnol Oceanogr 28: $465-476$

Falter JL, Sansone FJ (2000) Hydraulic control of pore water geochemistry within the oxic-suboxic zone of a permeable sediment. Limnol Oceanogr 45:550-557

Forster S, Huettel M, Ziebis W (1996) Impact of boundary layer flow velocity on oxygen utilisation in coastal sediments. Mar Ecol Prog Ser 143:173-185

Fung FMY, Tachibana S, Chou LM, Ding JL (1997) Cytotoxic and anticancer agents in mucus of Galaxea fascicularis: purification and characterization. J Mar Biotechnol 5:50-57

Glud RN, Klimant I, Holst G, Kohls O, Meyer V, Kuhl M, Gundersen JK (1999) Adaptation, test and in situ measurements with O-2 microopt(r)odes on benthic landers. Deep-Sea Res I 46:171-183

Graf G, Rosenberg R (1997) Bioresuspension and biodeposition: a review. J Mar Syst 11:269-278

Grenz C, Denis L, Boucher G, Chauvaud L, Clavier J, Fichez $\mathrm{R}$, Pringault O (2003) Spatial variability in sediment oxygen Consumption under winter conditions in a lagoonal system in New Caledonia (South Pacific). J Exp Mar Biol Ecol 285:33-47

Hall SJ (1994) Physical disturbance and marine benthic communities - life in unconsolidated sediments. Oceanogr Mar Biol Annu Rev 32:179-239

Hargrave BT (1969) Similarity of oxygen uptake by benthic communities. Limnol Oceanogr 14:801-805

Hines ME, Lyons WB (1982) Biogeochemistry of nearshore Bermuda sediments. 1. sulfate reduction rates and nutrient generation. Mar Ecol Prog Ser 8:87-94

Huettel M, Gust G (1992) Impact of bioroughness on interfacial solute exchange in permeable sediments. Mar Ecol Prog Ser 89:253-267

Huettel M, Rusch A (2000) Transport and degradation of phytoplankton in permeable sediment. Limnol Oceanogr 45:534-549

Huettel M, Ziebis W, Forster S (1996) Flow-induced uptake of particulate matter in permeable sediments. Limnol Oceanogr 41:309-322

Huettel M, Røy H, Precht E, Ehrenhauss S (2003) Hydrodynamical impact on biogeochemical processes in aquatic sediments. Hydrobiologia 494:231-236

Jørgensen BB (1977) Bacterial sulfate reduction within reduced microniches of oxidized marine sediments. Mar Biol 41:7-17

Jørgensen BB (1978) Comparison of methods for the quantification of bacterial sulfate reduction in coastal marinesediments. 1. Measurement with radiotracer techniques. Geomicrobiol J 1:11-27

Jørgensen BB (1982) Mineralization of organic-matter in the sea bed-the role of sulfate reduction. Nature 296:643-645 
Jørgensen BB (1990) A thiosulfate shunt in the sulfur cycle of marine-sediments. Science 249:152-154

Jørgensen BB, Bak F (1991) Pathways and microbiology of thiosulfate transformations and sulfate reduction in a marine sediment (Kattegat, Denmark). Appl Environ Microbiol 57:847-856

Kallmeyer J, Ferdelman TG, Weber A, Fossing H, Jørgensen BB (2004) A cold chromium distillation procedure for radiolabeled sulfide applied to sulfate reduction measurements. Limnol Oceanogr Methods 2:171-180

King GM, Carlton RG, Sawyer TE (1990) Anaerobic metabolism and oxygen distribution in the carbonate sediments of a submarine-canyon. Mar Ecol Prog Ser 58:275-285

Klute A, Dirksen C (1986) Hydraulic conductivity and diffusivity: laboratory methods. In: Klute A (ed) Method of soil analysis. Part 1: Physical and mineralogical methods, 2nd edn. American Society of Agronomy, Madison, WI, p 687-734

Krantzberg G (1985) The Influence of bioturbation on physical, chemical and biological parameters in aquatic environments - a review. Environ Pollut Ser A 39:99-122

Kristensen E (2000) Organic matter diagenesis at the oxic/anoxic interface in coastal marine sediments, with emphasis on the role of burrowing animals. Hydrobiologia 426:1-24

Krumholz LR, McKinley JP, Ulrich FA, Suflita JM (1997) Confined subsurface microbial communities in Cretaceous rock. Nature 386:64-66

Marnane MJ, Bellwood DR (2002) Diet and nocturnal foraging in cardinalfishes (Apogonidae) at One Tree Reef, Great Barrier Reef, Australia. Mar Ecol Prog Ser 231: 261-268

Nedwell DB, Blackburn TH (1987) Anaerobic metabolism in lagoon sediments from Davies Reef, Great Barrier Reef. Estuar Coast Shelf Sci 25:347-353

Oberdorfer JA, Buddemeier RW (1986) Coral-reef hydrology-field studies of water-movement within a BarrierReef. Coral Reefs 5:7-12

Pamatmat MM (1971) Oxygen consumption by seabed. 4. Shipboard and laboratory experiments. Limnol Oceanogr 16:536-550

Parnell KE (1986) Water-movement within a fringing-reef flat, Orpheus Island, North Queensland, Australia. Coral Reefs 5:1-6

Polerecky L, Franke U, Werner U, Grunwald B, de Beer D (2005) High spatial resolution measurement of oxygen consumption rates in permeable sediments. Limnol Oceanogr Methods 3:75-85

Precht E, Huettel M (2003) Advective pore-water exchange driven by surface gravity waves and its ecological implications. Limnol Oceanogr 48:1674-1684

Precht E, Franke U, Polerecky L, Huettel M (2004) Oxygen dynamics in permeable sediments with wave-driven pore water exchange. Limnol Oceanogr 49:693-705

Rasheed M, Badran MI, Richter C, Huettel M (2002) Effect of reef framework and bottom sediment on nutrient enrichment in a coral reef of the Gulf of Aqaba, Red Sea. Mar Ecol Prog Ser 239:277-285

Rasheed M, Badran MI, Huettel M (2003) Particulate matter filtration and seasonal nutrient dynamics in permeable carbonate and silicate sands of the Gulf of Aqaba, Red Sea. Coral Reefs 22:167-177

Rasheed M, Wild C, Franke U, Huettel M (2004) Benthic photosynthesis and oxygen consumption in permeable carbonate sediments at Heron Island, Great Barrier Reef, Australia. Estuar Coast Shelf Sci 59:139-150

Revsbech NP (1989) An oxygen microsensor with a guard cathode. Limnol Oceanogr 34:474-478

Revsbech NP, Jørgensen BB, Blackburn TH (1980) Oxygen in the sea bottom measured with a microelectrode. Science 207:1355-1356

Richter C, Wunsch M, Rasheed M, Kotter I, Badran MI (2001) Endoscopic exploration of Red Sea coral reefs reveals dense populations of cavity-dwelling sponges. Nature 413:726-730

Riddle MJ, Alongi DM, Dayton PK, Hansen JA, Klumpp DW (1990) Detrital pathways in a coral-reef lagoon. 1. Macrofaunal biomass and estimates of production. Mar Biol 104: 109-118

Rusch A, Huettel M, Forster S (2000) Particulate organic matter in permeable marine sands-dynamics in time and depth. Estuar Coast Shelf Sci 51:399-414

Shum KT, Sundby B (1996) Organic matter processing in continental shelf sediments - the subtidal pump revisited. Mar Chem 53:81-87

Skyring G (1985) Anaerobic microbial processes in coral reef sediments. Proc 5th Int Coral Reef Congr 3:421-425

Skyring GW, Chambers LA (1976) Biological sulfate reduction in carbonate sediments of a coral reef. Aust J Mar Freshw Res 27:595-602

Smith JS, Johnson CR (1995) Nutrient inputs from seabirds and humans on a populated coral cay. Mar Ecol Prog Ser $124: 189-200$

Thamdrup B, Hansen JW, Jørgensen BB (1998) Temperature dependence of aerobic respiration in a coastal sediment. FEMS Microbiol Ecol 25:189-200

Visscher PT, Reid RP, Bebout BM (2000) Microscale observations of sulfate reduction: correlation of microbial activity with lithified micritic laminae in modern marine stromatolites. Geology 28:919-922

Webb JE, Theodor J (1968) Irrigation of submerged marine sands through wave action. Nature 220:682-683

Webster IT, Norquay SJ, Ross FC, Wooding RA (1996) Solute exchange by convection within estuarine sediments. Estuar Coast Shelf Sci 42:171-183

Wentworth CK (1922) A scale of grade and class terms for clastic sediments. J Geol 30:377-392

Wenzhofer F, Holby O, Glud RN, Nielsen HK, Gundersen JK (2000) In situ microsensor studies of a shallow water hydrothermal vent at Milos, Greece. Mar Chem 69:43-54

Wheatcraft SW, Buddemeier RW (1981) Atoll-island hydrology. Ground Water 19:311-320

Wild C, Huettel M, Klueter A, Kremb SG, Rasheed MYM, Jørgensen BB (2004a) Coral mucus functions as an energy carrier and particle trap in the reef ecosystem. Nature 428: 66-70

Wild C, Rasheed M, Werner U, Franke U, Johnstone R, Huettel M (2004b) Degradation and mineralization of coral mucus in reef environments. Mar Ecol Prog Ser 267:159-171

Wilkinson CR (1987) Microbial ecology on a coral-reef. Search 18:31-33

Williams SL, Yarish SM, Gill IP (1985) Ammonium distributions, production, and efflux from backreef sediments, St-Croix, United-States Virgin Islands. Mar Ecol Prog Ser $24: 57-64$

Ziebis W, Huettel M, Forster S (1996) Impact of biogenic sediment topography on oxygen fluxes in permeable seabeds. Mar Ecol Prog Ser 140:227-237

Submitted: October 19, 2004; Accepted: September 2, 2005

Proofs received from author(s): February 15, 2006 